\title{
PENGEMBANGAN MULTIMEDIA TUTORIAL UNTUK MENDUKUNG GENERATIVE LEARNING BY SELF EXPLAINING
}

\author{
Sintia Larasati,Sulthoni, Saida Ulfa \\ Jurusan Teknologi Pendidikan, Fakultas Ilmu Pendidikan, Universitas Negeri Malang \\ Jalan Semarang 5 Malang 65145 0341-574700 \\ Email: sintialrs25@gmail.com
}

Article History

Received: 24 November 2020, Accepted: 12 Maret 2021, Published: 10 Agustus 2021

\begin{abstract}
Abstrak
Pebelajar membutuhkan media yang dapat memvisualkan materi yang bersifat abstrak dan menarik perhatian mereka sehingga dapat aktif dalam mengikuti pelajaran Biologi. Tujuan dari pengembangan ini adalah untuk menghasilkan produk multimedia yang berjenis tutorial berupa aplikasi media pembelajaran dengan teori belajar generative learning by self-explaining yang dapat digunakan dalam proses pembelajaran di SMAN 1 Kedungadem Kabupaten Bojonegoro. Produk yang dihasilkan yaitu berupa multimedia yang berjenis tutorial berupa aplikasi (.exe.) yang valid didalamnya terdapat materi berupa teks, gambar, audio, animasi dan video. Model penelitian dan pengembangan ini diadaptasi dari model penelitian pengembangan multimedia menurut Lee dan Owens. Hasil penelitian menunjukkan bahwa pada ahli pada media, ahli pada materi dan murid diperoleh hasil bahwa multimedia yang berjenis tutorial ditanggapi secara positif. Jadi dapat disimpulkan bahwa produk multimedia yang berjenis tutorial sistem pernapasan manusia ini termasuk dalam kriteria layak digunakan dalam kegiatan pembelajaran.
\end{abstract}

Keyword: Multimedia; Tutorial; Sistem Pernapasan

\begin{abstract}
Students needed a media that can visualize an abstract material and draw their attention in order for them to be active in taking Biology class. The purpose of this development is to produce a tutorial multimedia product in the form of learning media application with a Learning by Self-Explaining generative learning theory that can be used at SMAN 1 Kedungadem Bojonegoro Regency learning process. The product generated is a valid tutorial multimedia application (.exe.) that contains material such as texts, figures, audio, animations and videos. This research and development model is adapted from multimedia development research model by Lee and Owens. The result of this research showed that from the media experts, the material experts, and the students involved in the research, stated that this multimedia tutorial type brings positive impacts on the students. Therefore, it can be concluded that this tutorial media product on human respiratory system is eligible to be used in the teaching and learning process.
\end{abstract}

Keyword: Multimedia; Tutorials; Respiratory system 


\section{PENDAHULUAN}

Pengaruh dalam berbagai bidang di kehidupan manusia tidak dapat menghindari perkembangan teknologi informasi dan ilmu pengetahuan pada saat ini. Upaya-upaya pembaharuan dalam memanfaatkan hasil teknologi dalam proses pembelajaran sangat dibutuhkan, salah satunya pembaharuan di bidang pendidikan. Pada hakikatnya pembelajaran merupakan suatu proses interaksi antara guru dengan murid, baik interaksi secara langsung seperti kegiatan tatap muka maupun secara tidak langsung, yaitu menggunakan berbagai media pembelajaran (Rusman, 2012). Dari definisi tersebut, kegiatan pembelajaran adalah upaya agar terciptanya proses pembelajaran melalui hubungan antara murid dan guru, sumber belajar serta lingkungan agar tujuan yang diharapkan tercapai. Herdianto (2020) menyatakan bahwa, Cara dalam menyampaikan pembelajaran terhadap murid menggunakan berbagai strategi, metode, serta media untuk pembelajaran yang bermakna.

Untuk meningkatkan kualitas hasil pembelajaran diperlukan perangkat lunak (software) aplikasi pendidikan dengan bantuan komputer berbasis multimedia yang lebih komunikatif dan interaktif (Munir, 2012). Aplikasi pembuatan media untuk pembelajaran merupakan salah satu aplikasi yang saat ini sedang dikembangkan pada dunia pendidikan. Sihkabudhen (2011) menyebutkan bahwa, Media adalah sarana atau alat atau perangkat yang menjadi saluran, perantara atau jembatan dalam kegiatan komunikasi antara penyampai pesan (komunikator) dan penerima pesan (komunikan). Dari definisi tersebut, proses pembalajaran yang awalnya berpusat pada guru dapat diubah menjadi berpusat kepada murid dengan menggunakan media untuk pembelajaran. Menurut Jatmika (2005), Media untuk pembelajaran yang menarik serta layak memberikan dampak positif pada kegiatan pembelajaran.

Berdasarkan hasil wawancara (tanya jawab) di SMA Negeri 1 Kedungadem yang telah dilakukan oleh peneliti, kegiatan pembelajaran yang terjadi yaitu guru menyampaikan materi dengan metode konvensional, jadi pembelajaran sesuai dengan petunjuk dari guru dan hanya berpusat pada guru. Murid hanya menyimak, mendengar, dan mencatat penjelasan materi yang disampaikan oleh guru. Menurut Lazuardi (2018) Solusi untuk mengatasi kendala dalam memahami materi pembelajaran yaitu dengan menerapkan multimedia interaktif dalam media penunjang pembelajaran di kelas. Media untuk pembelajaran yang umumya digunakan saat pembelajaran biologi berupa buku paket, LKS (Lembar Kerja Murid), serta slide power point. Menurut Widodo (2016), Kualitas pendidikan Indonesia rendah, begitu pula dengan pembelajaran sains termasuk IPA. Selain itu dalam proses pembelajaran biologi masih mengguanakan metode kovensional dimana pembelajaran hanya berpusat pada guru dan murid menjadi audiens. Hal ini menyebabkan proses pembelajaran menjadi kurang bermakna bagi murid, dengan begitu guru sebaiknya memanfaatkan multimedia interaktif untuk keberhasilan kegiatan pembelajaran (Nurullah, 2019). Hal ini seperti pendapat Prastiwi (2020), Guru dituntut memberikan inovasi baru agar murid mampu mendapatkan pengalaman baru dalam kegiatan pembelajaran.

Salah satu cara untuk mengaktifkan anak didik dalam memberikan tanggapan, feedback, serta mendorong anak didik untuk melakukan praktik-praktik yang benar adalah menggunakan media untuk pembelajaran yang baik. Hal tersebut dapat dilakukan melalui pembelajaran berbasis multimedia yang berjenis tutorial. Menurut Rusman (2012) Tutorial merupakan bimbingan pebelajaran dalam bentuk pemberian arahan, bantuan, petunjuk, dan motivasi agar anak didik belajar secara efisien dan efektif. Sedangkan menurut Alessi dan Trollip (2001), Tutorial adalah pembelajaran yang dimulai dengan manyajikan informasi, serta membimbing murid dalam mempelajari informasi. Pada multimedia yang berjenis tutorial, anak didik dituntut untuk aktif dalam membaca dan mempelajari materi agar dapat menyelesaikan setiap latihan soal yang disajikan di setiap submateri dalam multimedia yang berjenis tutorial serta murid dapat menjelaskan menurut pemahamannya sendiri diakhir pembelajaran, hal tersebut mengakibatkan anak didik dapat lebih mengingat materi pembelajaran yang telah dipelajari. Menurut Atmaja (2019), Multimedia yang berjenis tutorial ini dapat membuat anak murid mengalami 
pembelajaran individual sehingga pembelajaran akan lebih bermakna jika menggunakan multimedia yang berjenis tutorial.

Dalam multimedia yang berjenis tutorial ini terdapat teori belajar generative yaitu Learning by Self-explaining atau belajar dengan menjelaskan sendiri. Penambahan teori belajar dalam multimedia yang berjenis tutorial ini bermaksud untuk meningkatkan kembali minat baca anak didik menggunakan multimedia yang berjenis tutorial yang dikemas dengan tampilan yang menarik perhatian anak didik dan mudah dioperasikan sehingga anak didik tidak merasa bosan saat belajar. Sejalan dengan teori pembelajaran generatif, belajar dengan menjelaskan diri sendiri akan menjadi cara yang efektif ketika anak didik memilih dan mengambil informasi yang penting dari pelajaran dan menyatakan informasi tersebut kembali dengan kata-kata mereka sendiri (mirip dengan meringkas), kemudian menghasilkan kesimpulan untuk membuat materi menjadi bayangan atau pemikiran yang mudah dimengerti sehingga anak didik dapat menggabungkan materi dengan pengetahuan mereka sebelumnya. Penambahan teori belajar dengan menjalaskan sendiri ini disajikan dalam bentuk essay kategori evaluasi dengan jawaban bebas diakhir pembelajaran menggunakan multimedia yang berjenis tutorial.

Salah satu media yang digunakan dalam pembelajaran biologi adalah menggunakan benda asli (real object). Dalam pelaksanaannya, pemanfaatan benda asli dalam kegiatan pembelajaran di sekolah masih jarang dijumpai dengan berbagai alasan. Oleh karena itu diperlukan alternatif media selain benda asli (real object) dalam pembelajaran biologi. Salah satunya dapat menggunakan multimedia berbasis Information and Communication Technology (ICT) tujuannya agar mengoptimalkan proses pembelajaran.Menggunakan teknologi dalam pembelajaran mempunyai kelebihan seperti, mempermudah murid dalam belajar dengan warna-warna, gambar, suara, video, animasi sehingga proses belajar menjadi efisien.

\section{METODE}

Produk ini dikembangkan dalam bentuk aplikasi Multimedia yang berjenis tutorial Sistem pernapasan manusia Kelas XI IPA SMA Negeri 1 Kedungadem Kabupaten Bojonegoro. Dalam membuat aplikasi multimedia berjenis tutorial ini yaitu menggunakan aplikasi Lectora Inspire 17 Media Studio. Model penelitian dan pengembangan ini diadaptasi dari Lee dan Owens (2004) yang memiliki beberapa tahapan yang perlu dilakukan yang dapat dilihat pada Gambar 1.

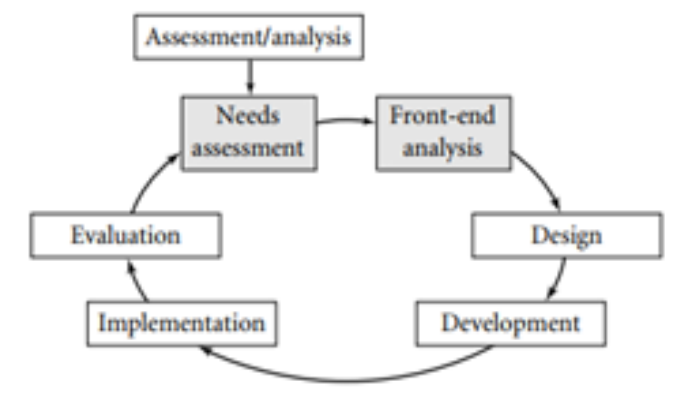

\section{Gambar 1. Model Penelitian Pengembangan Lee dan Owens (2004)}

Prosedur penelitian dan pengembangan yang digunakan dalam multimedia yang berjenis tutorial ini adalah: (1) Tahap Analisis yang meliputi Need Assessment (Analisis Kebutuhan) dan Front-End Analysis (Analisis Awal-Akhir); (2) Tahap Desain yang meliputi dari Jadwal Pengembangan, Spesifikasi Produk, Struktur Materi serta Kontrol Konfigurasi; (3) Tahap Pengembangan; (4) Tahap Implementasi dan (5) Tahap Evaluasi.

Desain uji coba pada pengembangan multimedia yang berjenis tutorial ini yaitu terdiri dari uji coba ahli pada media dan ahli pada materi, tanggapan murid serta uji lapangan. Tanggapan dilakukan oleh murid jurusan bahasa kelas XI SMAN 1 Kedungadem Kab. Bojonegoro bertujuan untuk 
mengukur kelayakan multimedia yang berjenis tutorial yang digunakan dalam kegiatan pembelajaran. Prosedur pelaksanaan uji coba lapangan untuk pemanfaatan multimedia meliputi, diawali dengan dapat menjelaskan kepada guru maksud serta tujuan mengadakan uji coba lapangan pada multimedia berjenis tutorial yang diproduksi. Tahap desain mencakup serangkaian seluruh kegiatan yang dilakukan dalam pengembangan, seperti membuat jadwal kegiatan, spesifikasi media, struktur konten atau materi, serta kontrol konfigurasi yang sesuai dengan multimedia yang berjenis tutorial ini. Untuk menguji kelayakan multimedia untuk pembelajaran yang berjenis tutorial materi sistem pernapasan manusia pada ahli pada media, ahli pada materi dan murid atau audiens, dilakukan pada tahap pengembangan. Multimedia yang berjenis tutorial ini dikembangkan menggunakan software Lectora Inspire 17 Media Studio untuk mengolah seluruh tampilan multimedia yang berjenis tutorial yang dikembangkan, dan menggunakan Adobe Photoshop sebagai software penunjang untuk mengolah gambar.

Dalam penelitian ini, tahap implementasi dan evaluasi belum dilakukan karena perangkat masih dalam tahap uji kelayakan dengan tahap kesiapan teknologi (TKT) pada peringkat 4 yaitu validasi kode, komponen serta atau kumpulan komponen dalam lingkungan laboratorium. Pengujian kelayakan multimedia yang berjenis tutorial yang dikembangkan ini dilakukan oleh ahli pada media dari salah satu dosen jurusan teknologi pendidikan UM dan ahli pada materi dari guru Biologi di SMAN 1 Kedungadem serta diujicobakan kapada kelompok kecil pada murid kelas XI sebanyak 5 orang, disini murid mengisi angket tanggapan yang telah disediakan dalam bentuk google form. Dalam mengetahui penilaian kriteria tingkat kelayakan pada angket menggunakan analisis data rating scale sebagai berikut: Sangat Setuju bernilai (4), Setuju bernilai (3), Tidak setuju bernilai (2), serta Sangat tidak setuju bernilai(1).

\section{HASIL}

Penggunaan teknik dalam mengumpulkan data bertujuan untuk menganalisa kebutuhan atau masalah dengan menentukan solusi untuk memperoleh data kebutuhan lapangan yang lebih akurat (Lee dan Owens, 2004). Menurut hasil wawancara (tanya jawab) yang sudah dilakukan di SMAN 1 Kedungadem terhadap guru Mata Pelajaran Biologi, anak didik mampu menjalankan komputer dengan baik, namun seringkali murid merasa bosan dalam kegiatan pembelajaran. Fasilitas laboratorium komputer sudah terbilang lengkap sejumlah murid, namun belum dimanfaatkan secara optimal. Pada lingkungan belajar di sekolah tergolong kondusif, tertib, dan nyaman sehingga kendala pada lingkungan belajar tidak ditemukan. Sumber belajar yang digunakan untuk mengembangkan multimedia berjenis tutorial ini sudah pernah diajarkan sebelumnya, lalu diberikan kembali pada anak didik melalui sebuah bentuk produk multimedia yang berjenis tutorial. Pemanfaatan produk berupa multimedia yang berjenis tutorial yang dilakukan dengan cara menganalisis daftar tugas yang harus diselesaikan dengan baik oleh murid IPA Kelas XI SMAN 1 Kedungadem Kab. Bojonegoro sesuai dengan materi yang pernah diajarkan sebelumnya, yaitu berupa materi beserta latihan soal yang ada di dalamnya mengenai materi Sistem pernapasan manusia, serta hal yang tidak seharusnya dilakukan selama pelaksanaan yaitu memberikan sesuatu yang belum penah diajarkan oleh guru atau pelajaran yang seharusnya ada di semester berikutnya.

SMAN 1 Kedungadem memiliki fasilitas yang dapat menunjang pengembangan dalam multimedia yang berjenis tutorial. Pihak sekolah khususnya guru pada pelajaran Biologi menghasilkan tanggapan yang positif terhadap pengembangan multimedia yang berjenis tutorial ini. Pada multimedia yang berjenis tutorial pokok bahasan Sistem pernapasan manusia yang disebutkan di silabus kelas 11 semester 2, sehingga tujuan dalam pembelajaran tercapai. Multimedia berjenis tutorial tergolong pada komputer-based dikarenakan pembelajaran memanfaatkan media berupa perangkat komputer sebagai perantara dan anak didik dapat berinteraksi sendiri secara langsung dengan multimedia yang berjenis tutorial ini. Pengembangan multimedia yang berjenis tutorial ini telah diselaraskan dengan 
Kompetensi Inti serta Kompetensi Dasar yang disebutkan di silabus Biologi Kelas XI IPA semester II SMAN 1 Kedungadem Kab. Bojonegoro. Sehingga mendapatkan hasil berupa produk yang sesuai dengan kemampuan murid saat ini. Kesimpulan yang dihasilkan selama melakukan proses pengembangan tidak dipaparkan rincian biaya yang dikeluarkan untuk proses produksi multimedia yang berjenis tutorial Sistem pernapasan manusia. Interface produk multimedia yang berjenis tutorial yang dikembangkan diperlihatkan pada gambar 2.

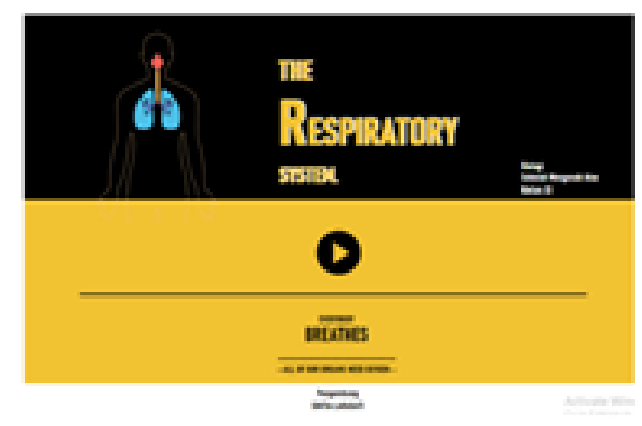

Tampilan awal

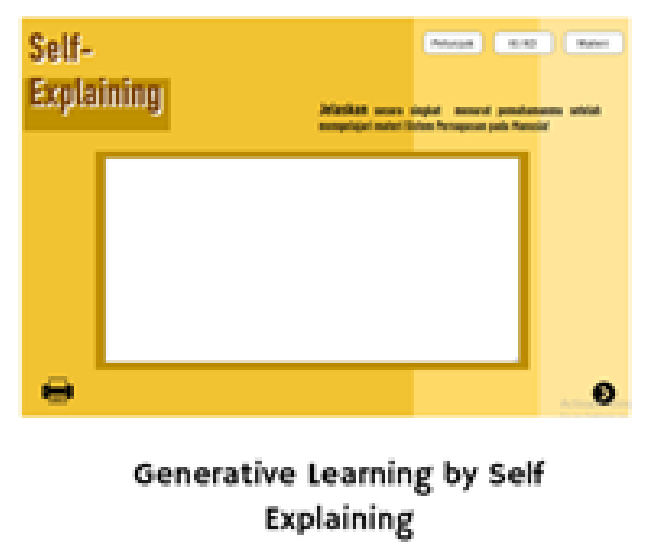

Explaining

Gambar 2. Tampilan Interface Produk

Data uji coba produk pengembangan media bagi pembelajaran ini dilaksanakan dua tahap. Perolehan data uji coba tahap awal berasal dari hasil pemberian nilai oleh ahli pada media, sedangkan tahap kedua diperoleh dari tenaga didik pelajaran Biologi di SMAN 1 Kedungadem sebagai ahli pada materi. Hasil penyajian data uji coba ahli pada media ada dua, yaitu data kuantitatif yang berbentuk angka dan saran ditunjukkan pada Gambar 3.

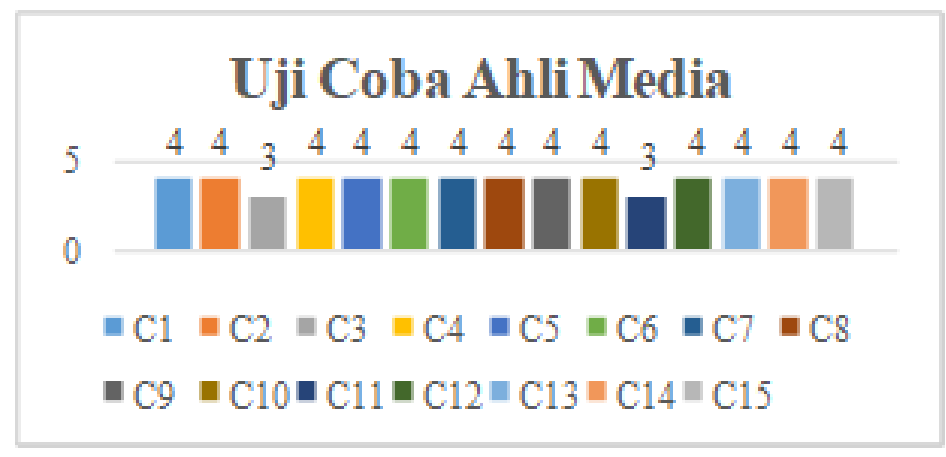

Gambar 3. Hasil Tanggapan Ahli Media

Berdasarkan data uji coba ahli pada mediapada gambar 2, multimedia yang berjenis tutorial bernilai positif serta bisa dikatakan bahwa Pengembangan Multimedia yang berjenis tutorial pokok bahasan Sistem pernapasan manusia Layak untuk dipakai karena dari penyajian 15 bentuk pernyataan terdapat 13 penyataan yang memiliki nilai 4 , dan 2 pernyataan bernilai 3 . Selain pernyataan, ahli pada media juga memberikan beberapa tanggapan bahwa pengembangan multimedia yang berjenis tutorial sistem pernapasan manusia secara luas sudah cukup bagus, namun ditemukan beberapa hal yang perlu diperbaiki diantaranya yaitu perbaikan dalam petunjuk penggunaan serta sumber referensi yang tepat.

Setelah dilakukan uji coba ahli pada media oleh satu dosen Jurusan TEP UM ditentukan hasil dalam bentuk data dari instrumen angket. Hasil angket Pengembangan Multimedia yang berjenis tutorial Sistem pernapasan manusia kelas IX Di SMAN 1 Kedungadem disajikan pada lampiran. Hasil penyajian data uji coba ahli pada materi ditunjukkan pada Gambar 4. 


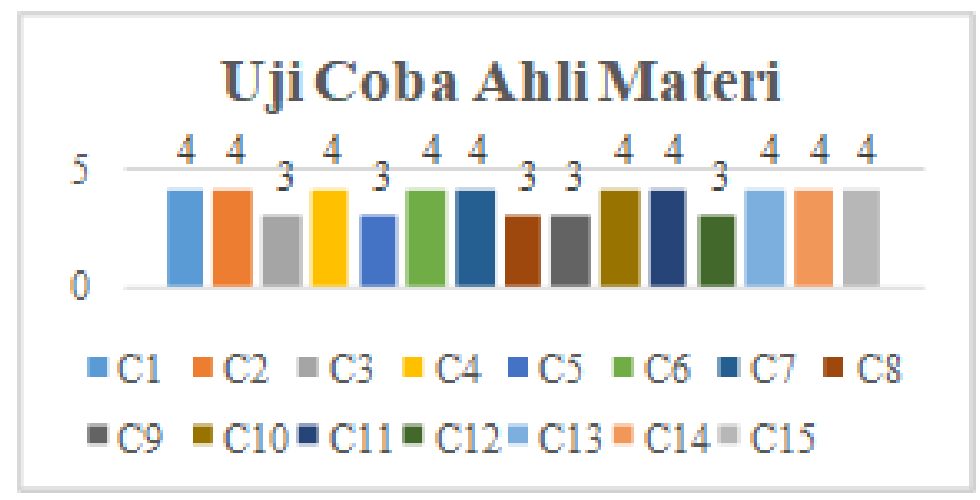

Gambar 4. Hasil Tanggapan Ahli Materi

Berdasarkan data uji coba dari ahli pada materi pada gambar 3 multimedia yang berjenis tutorial bernilai positif serta bisa dikatakan bahwa Pengembangan Multimedia yang berjenis tutorial pokok bahasan Sistem pernapasan manusia Layak untuk dipakai karena dari penyajian 15 bentuk pernyataan terdapat 10 penyataan yang memiliki nilai 4 , serta 5 bentuk pernyataan bernilai 3.Selain pernyataan, ahli pada materi juga memberikan beberapa tanggapan bahwa pengembangan multimedia yang berjenis tutorial sistem pernapasan manusia secara luas sudah baik serta dapat mempermudah murid dalam memahami materi, namun ada beberapa hal yang harus diperbaiki diantaranya yaitu jika bisa keterangan gambar diganti dengan Bahasa Indonesia, menambahkan materi tentang volume udara pernapasan dan menggunakan istilah yang sederhana.

Pada pengembangan multimedia yang berjenis tutorial ini, uji coba produk dilakukan pada kelompok kecil murid kelas XI sebanyak 5 orang. Disini murid mengisi angket tanggapan untuk murid yang diisi melalui google form yang telah disediakan. Data hasil tanggapan murid disajikan pada Gambar 5.

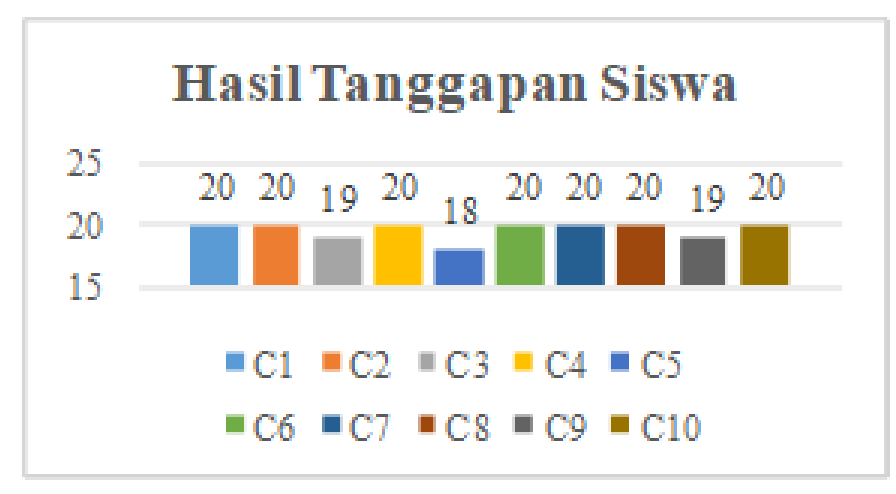

\section{Gambar 5. Hasil Tanggapan Murid}

Berdasarkan hasil analisis data angket tanggapan murid pada gambar 4, multimedia yang berjenis tutorial ini bernilai positif dan dapat dikatakan bahwa Pengembangan Multimedia yang berjenis tutorial Materi Sistem pernapasan manusia Layak untuk digunakan. Murid juga memberikan tanggapan bahwa multimedia yang berjenis tutorial ini memiliki tampilan yang sangat menarik dengan perpaduan warna, layout dan kejelasan audio. Selain itu murid juga memberikan beberapa catatan pada ukuran font yang digunakan dapat lebih diperbesar, agar pembelajaran menggunakan multimedia ini menjadi lebih efektif.

\section{PEMBAHASAN}

Ilmu pengetahuan telah berkembang seiring zaman, proses pembelajaran juga membutuhkan sarana dan prasarana yang optimal untuk perkembangan berpikir murid kritis. Penggunaan multimedia untuk proses pembelajaran menjadi suatu bentuk perkembangan teknolgi dalam konteks pendidikan. Suatu 
aplikasi sekarang sedang dikembangkan dalam konteks pendiidkan adalah penciptaan media untuk pembelajaran. Munir (2012) menjelaskan untuk menaikkan kualitas hasil pembelajaran dibutuhkan perangkat lunak (software) aplikasi pendidikan dengan bantuan komputer berbasis multimedia yang sangat komunikatif serta interaktif. Menurut Rahardjo (2019) menyebutkan bahwa, pembelajaran dengan menggunakan teknologi akan meningkatkan ketertarikan serta minat belajar.

Dari penelitian yang sudah dilaksanakan sebelumnya oleh M. Azwar Anas (2018) memaparkan bahwa multimedia yang berjenis tutorial memberikan pengalaman pembelajaran yang sangat interaktif, mandiri, dan sangat variatif. Namun dalam pengoperasian multimedia yang berjenis tutorial tersebut belum terdapat teori belajar generative learning by self-explaining (belajar dengan menjelaskan sendiri) yang diinginkan dapat dilaksanakan dalam pembelajaran.

Pengembangan multimedia yang berjenis tutorial merupakan penyempurnaan dari pengembangan yang sudah dilaksanakan sebelumnya dengan didukung desain interface yang menarik, audio, video dan animasi sebagai pendukung agar murid dapat dengan mudah memahami pokok bahasan yang disampaikan, terdapat soal pada setiap sub pokok bahasan yang wajib dikerjakan murid agar dapat lanjut ke materi selanjutnya. Pada akhir pembelajaran menggunakan multimedia yang berjenis tutorial ini terdapat teori belajar generatif learning by self explaining dimana murid harus menjelaskan kembali pokok bahasan yang telah dipelajari menurut pemahamannya sendiri. Menurut Atmaja (2019), Namun dalam pengoperasian multimedia yang berjenis tutorial masih dibutuhkan peran pendidik untuk mengawasi murid (Maura, 2020). Yunita (2019) menyebutkan kalau media merupakan pokok utama dalam aktifitas belajar mengajar serta tidak hanya sebagai menjadi alat pendukung dalam mengajar. Hal ini sejalan dengan pernyataan yang disampaikan oleh (Rahardjo, Degeng, \& Soepriyanto, 2019) "Peran pendidik hanya memastikan murid belajar secara disiplin hingga menyelesaikan semua tahapan pokok bahasan multimedia yang berjenis tutorial".Multimedia yang berjenis tutorial ini memiliki kelebihan dan kekurangan dalam penggunaannya. Pengembangan multimedia yang berjenis tutorial ini diuji kelayakannya kepada ahli pada media, ahli pada pokok bahasan dan diujicobakan kepada beberapa murid.

Sebenarnya murid sudah dibantu oleh petunjuk dalam multimedia namun, peran pendidik yang diperlukan disini hanya untuk melihat murid belajar dengan disiplin dan bisa menyelesaikan semua tahapan dengan baik, sehingga murid dapat menjelaskan kembali pokok bahasan yang telah dipelajari menurut pemahamannya sendiri sesuai dengan teori belajar generatif learning by self-explaining. Penambahan teori belajar generatif Learning by self-explaining atau menjelaskan sendiri pada multimedia yang berjenis tutorial yang diujicobakan kepada beberapa murid kelas 11 SMAN 1 Kedungadem menunjukkan nilai yang positif. Secara keseluruhan murid dapat dengan mudah mengoperasikan multimedia yang berjenis tutorial dan mampu menyelesaikan soal serta mampu menjelaskan kembali pokok bahasan yang telah dipelajari dengan baik, karena pembelajaran menggunakan multimedia yang berjenis tutorial murid diharuskan untuk mempelajari pokok bahasan dengan sungguh-sungguh agar dapat mengerjakan latihan soal pada setiap sub pokok bahasan dan dapat melanjutkan ke pokok bahasan selanjutnya. Murid dapat menjelaskan kembali menurut pemahamannya sendiri pada akhir pelajaran sehingga murid dapat dengan mudah mengingat pokok bahasan yang telah dipelajari.Belajar dengan menjelaskan sendiri dapat mendorong murid untuk menghasilkan penjelasan sendiri selama pembelajaran dan membantu proses pemahaman murid sehingga dapat memberikan hasil pembelajaran yang optimal (Fiorella, Mayer 2015).

Pengembangan ini diujicobakan ke Ahli pada pokok bahasan dan Ahli pada media. Ada 15 aspek pernyataan yang berhubungan dengan pokok bahasan system pernapasan pada manusia yang dijelaskan dalam multimedia yang berjenis tutorial. Angket yang diberikan kepada Ahli pada media dalam skala 1-4, menghasilkan penilaian 4 yaitu pada aspek kemenarikan pada desain interface, kesesuaian icon, kesesuaian audio/suara, keterpaduan komponen multimedia, tingkat kemudahan 
pengoperasian pada multimedia dan kemutakhiran media termasuk dalam kriteria valid. Sedangkan kesesuaian membangkitkan kreativitas murid dan ketepatan ukuran teks termasuk dalam kriteria cukup valid dengan hasil penilaian 3 dalam skala 1-4. Pada angket Ahli pada media juga terdapat catatan dari Ahli pada media yaitu secara umum sudah cukup bagus, namun perlu dilengkapi dengan petunjuk pemanfaatan yang baik dan sumber referensi yang baik.

Pada angket yang diberikan kepada ahli pada pokok bahasan dalam skala 1-4 menghasilkan penilaian 4 yaitu pada aspek kesesuaian layout, kesesuaian latihan soal dengan tingkat kemampuan murid, dan kemudahan murid dalam mengerjakan latihan soal termasuk dalam kriteria valid. Sedangkan keaukaratan istilah-istilah, keakuratan antar kegiatan belajar/sub kegiatan belajar/alinea pada dan kesesuaian pokok bahasan dengan perkembangan Ilmu Pengetahuan media termasuk dalam kriteria cukup valid dengan hasil penilaian 3 dalam skala 1-4. Pada hasil penilaian angket ahli pada media terdapat beberapa catatan yaitu manusia secara umum sudah bagus dan dapat mempermudah murid dalam memahami pokok bahasan, namun ada beberapa hal yang harus diperbaiki diantaranya yaitu jika bisa keterangan gambar diganti dengan Bahasa Indonesia, menambahkan pokok bahasan tentang volume udara pernapasan dan menggunakan istilah yang sederhana.

Pada angket uji coba yang diberikan kepada murid terdapat 10 aspek pertanyaan dan menghasilkan jawaban yang diharapkan 4 yaitu pada aspek pertanyaan mengenai tampilan yang menarik, wara yang digunakan menarik, jenis font yang digunakan menarik, kejelasan audio dalam multimedia, keterpaduan antar gambar, teks, audio, gambar yang digunakan menarik, dan dapat mempermudah proses pembelajaran pokok bahasan system pernapasan pada manusia dengan menggunakan multimedia yang berjenis tutorial ini. Berdasarkan hasil dariangket murid maka dapat disimpulkan bahwa secara keseluruhan murid dapat dengan mudah mengoperasikan multimedia yang berjenis tutorial dan mampu mengerjakan latihan soal yang disajikan dengan baik dan juga murid lebih suka melaksanakan pembelajaran dengan menggunakan komputer karena menjadikan pembelajaran menjadi lebih variatif degan penggunaan desain yang menarik dapat meningkatkan minat baca murid dalam mempelajari pokok bahasan system pernapasan pada manusia.

Setelah dilakukan beberapa perbaikan berdasarkan hasil uji coba multimedia yang berjenis tutorial untuk mendukung generative leraning ini ini memiliki beberapa kelebihan sebagai berikut: 1) Produk multimedia yang berjenis tutorial ini memiliki desain yang menarik, 2) Gambar dan penjelasan pada multimedia disampaikan secara singkat dan jelas sehingga dapat mempermudah murid dalam memahami pokok bahasan, 3) Latihan soal yang disajikan pada produk multimedia yang berjenis tutorialsesuai dengan tingkat kemampuan murid, 4) Penambahan teori generatiflearning by self explaining memudahkan murid dalam menghasilkan kesimpulan sendiri di akhir proses pembelajaran.

\section{SIMPULAN}

Multimedia ini telah diujicobakan pada murid kelas XI di SMA Negeri 1 kedungadem. Sebelum melaksanakan uji coba, produk pengembangan diserahkan kepada ahli pada media dan ahli pada pokok bahasan terlebih dahulu untuk mengetahui kelayakan produk yang akan dikembangkan. Pada ahli pada media, dikatakan jika multimedia yang berjenis tutorial ini layak digunakan di lapangan, pada ahli pada pokok bahasan dikatakan jika multimedia yang berjenis tutorial ini layak digunakan di lapangan. Hanya ada beberapa yang harus diperbaiki seperti penambahan materi dan penggunaan istilah yang sederhana.

Uji coba produk juga dilakukan pada kelompok kecil dan didapatkan hasil bahwa secara keseluruhan murid dapat dengan mudah mengoperasikan multimedia yang berjenis tutorial dan mampu mengerjakan latihan soal yang disajikan dengan baik dan juga murid lebih suka melaksanakan pembelajaran dengan menggunakan komputer karena menjadikan pembelajaran menjadi lebih variatif. 


\section{DAFTAR RUJUKAN}

Alessi, S. M., \& Trollip, S. R. (2001).Multimedia for Learning: Methods and Development (3rd ed.). Boston: Allyn and Bacon.

Amalia, S. M., Ulfa, S., \& Soepriyanto, Y. (2020). Multimedia tutorial Berbasis Android Untuk Memudahkan Murid Memahami Materi Mengenal Notasi Balok Kelas X Seni Musik. Jurnal Kajian Teknologi Pendidikan, 3(1), 59-67.

Anas, M. A., Soepriyanto, Y., \& Susilaningsih, S. (2019). Pengembangan Multimedia tutorial Topologi Jaringan Untuk Smk Kelas X Teknik Komputer Dan Jaringan. Jurnal Kajian Teknologi Pendidikan, 1(4), 307-314.

Atmaja, S., \& Surahmat, A. (2019).Media Pembelajaran Desain Web Menggunakan Photoshop CS6 dan Adobe Dreamweaver Berbasis Multimedia.Jurnal SIMIKA, 2(1), 1-18. DOI: https://doi.org/10.47080/simika.v2i1.276.

Fiorella, L., \& Mayer, R. (2015).Learning as a Generative Activity: Eight Learning Strategies that Promote Understanding. New York: Cambridge University Press.

Herdiyanto, M, D., Sulton., \& Praherdhiono, H. (2020). Pengembangan Multimedia Pembelajaran Interaktif Pada Materi Tema Tanah Bagi Siswa Tunagrahita. Jurnal Kajian Teknologi Pendidikan. 3(1). 88-96.

Jatmika,H.M.(2005).Pemanfaatan Media Visual dalam Menunjang Pembelajaran Pendidikan Jasmani di Sekolah Dasar. Jurnal Pendidikan Jasmani Indonesia, 3(1),89-99.

Lazuardi, Wisnu. (2018). Pengembangan Multimedia Interaktif Pelajaran Baca Tulis Aksara Jawa Dengan Sandhangan. Jurnal Inovasi dan Teknologi Pendidikan. Vol. 4, No. 2.

Lee, W. W., \& Owens, D. L. (2004). Multimedia-Based Instructioanal Design. San Francisco: Pfeiffer.

Mawarni, Sella \& Muhtadi, Ali. (2017). Pengembangan Digital Book Interaktif Mata Kuliah Pengembangan Multimedia Pembelajaran Interaktif Untuk Mahasiswa Teknologi Pendidikan. Jurnal Inovasi Teknologi PendidikanVol 4 (1). 84-96.

Mayer, R. E. (2009). Multimedia Learning: Prinsip-Prinsip dan Aplikasi (T. W. Utomo, Trans.). Yogyakarta: Pustaka Pelajar.

Munir. (2012). Multimedia: Konsep \& Aplikasi dalam Pendidikan. Bandung: Alfabeta.

Novita Sholehatul U., Eka Pramono A., Saida U. (2019). Multimedia tutorial Untuk Menumbuhkan Minat Baca Anak Adhd (Attention Deficit Hyperactivity Disorder). Jurnal Kajian Teknologi Pendidikan, 2(1).

Nurullah, A., Soepriyanto, Y., Sulton, S., \& Husna, A. (2019). Pengembangan Multimedia Pembelajaran Energi dalam Sistem Kehidupan. Jurnal Kajian Teknologi Pendidikan, 2(4), 315319.

Prastiwi, N.D., Setyosari, P., \& Husna, A. (2020). Pengembangan Multimedia tutorial Sebagai Suplemen Pada Mata Pelajaran Kimia Materi Asam Dan Basa Kelas XI. Jurnal Kajian Teknologi Pendidikan, 6 (2), 69-80.

Rahardjo, T., Degeng, I. N. S., \& Soepriyanto, Y. (2019). Pengembangan Multimedia Interaktif Mobile Learning Berbasis Anrdroid Aksara Jawa Kelas X Smk Negeri 5 Malang. Jurnal Kajian Teknologi Pendidikan, 2(3), 195-202.

Rusman. (2012). Model-Model Pembelajaran: Mengembangkan Profesionalisme Guru. Jakarta: Raja Grafindo Persada.

Sihkabuden.(2011). Media Pembelajaran. Malang: Fakultas Ilmu Pendidikan Universitas Negeri Malang.

Shinta Kusuma W., Punaji S., Arafah H. (2019). Pengembangan Multimedia tutorial Mata Pelajaran Ipa Pokok Bahasan Sistem Tata Surya Kelas Vii Mts Raudlatul Ulum Karangploso. Jurnal Kajian Teknologi Pendidikan, 2(1). 
Sutopo, A.H. (2003). Multimedia Interaktif dengan Flash. Yogyakarta: Graha Ilmu.

Sungkono.(2007). Peran Benda Asli dan Pemanfaatannya dalam Proses Pembelajaran di Sekolah Dasar.Majalah Ilmiah Pembelajaran, 3(1), 27-36.

Wardani, S. K., Setyosari, P., \& Husna, A. (2019). Pengembangan Multimedia tutorial Mata Pelajaran Ipa Pokok Bahasan Sistem Tata Surya Kelas Vii Mts Raudlatul Ulum Karangploso. Jurnal Kajian Teknologi Pendidikan, 2(1), 23-29.

Warnadi. 2010. Penerapan media pembelajaran Tutorial Adobe Capteivate dalam Meningkatkan Hasil Belajar Siswa Kelas XI Pada Pokok Bahasan Sel di SMA Negeri 5 Kota Cirebon (Skripsi). Cirebon: IAIN Syekh Nurjati.

Widodo, H. (2016). Potret pendidikan di indonesia dan kesiapannya dalam menghadapi masyarakat ekonomi asia (MEA). Cendekia: Journal of Education and Society, 13(2), 293. https://doi.org/10.21154/cendekia.v13i2.250.

Yunita, R., Praherdhiono, H., \& Adi, E. P. (2019). Pengembangan Multimedia Interaktif Materi Fotosintesis untuk Siswa Kelas VIII Sekolah Menengah Pertama. Jurnal Kajian Teknologi Pendidikan, 2(4), 284-289. 